\title{
DETAILED ANAL YSIS OF 30 FERTELIZER DEMONSTRATIONS IN SOUTHERN THAILAND
}

\author{
by \\ J. Dootson ${ }^{1}$, J.R.J. Moss², Sura Rungreung ${ }^{3}$, \\ Saowannee Meemuth ${ }^{4}$, K. Ryder ${ }^{5}$, Maliwan Rattanapruk ${ }^{6}$
}

\section{SUMMARY}

Twice-yearly coconut counts taken from 30 different demonstrations on Thai Tall palms showed that applying fertilizer increased the number of nuts produced over the 3 years studied. Application of $2 \mathrm{~kg}$ of a 13:13:21 NPK compound was -shown to be more cost effective than applying $4 \mathrm{~kg}$ of the same compound, but was rarely profitable, as the largest responses occurred in years when yields were high and the farmgate prices were at their lowest.

Sites where nut counts from unfertilized plots were high showed much smaller responses to applied fertilizer than those having lower counts, suggesting that inherently low yielding plots are more likely to respond to applied fertilizer. Nut counts can be considered a simple, cheap and reliable method of anticipating the probability of a fertilizer response.

Foliar and soil analyses showed few consistent relationships with the nut counts and the calculated multiple regression equations failed to account for $60 \%$ of the variation. Examination of all plots showed that foliar nitrogen was more often significantly correlated with the nut counts than any of the other variates but, when only the unfertilized plots were examined, the foliar and soil phosphate levels were more dominant; suggesting that the inherent yields are determined more by the phosphate levels while foliar nitrogen is. a measure of the success of fertilizer strategies.

It is concluded that if a more profitable increase in yield of Thai Tall coconuts is to be achieved in the smallholder sector then a lower fertilizer recommendation needs to be developed.

\section{INTRODUCTION}

Although it has long been known that inorganic fertilizers increase coconut yields, it has been estimated that $99 \%$ of coconut farmers use no fertilizer other than common salt and household and farmyard waste (Von Uexkull, 1985). Most of the world's coconut production is in the hands of smallholders who make rational economic decisions based on their own socio-economic circumstances. In the case of fertilizer applications to coconuts, these decisions are influenced by (1) the length of time before there is any return for the investment, (2) the low and erratic yields of the local Tall palms, and (3) the sensitivity of world and, especially, local oilseed markets to the supply. Where tropical rather than equatorial climate predominates, much of the potential benefit from applying fertilizer may be nullified by drought. Yield distribution under these conditions is also seasonal and is not balanced out by fertilizer application, so that the increase in crop coincides with the times of lowest product value,

1/ Team. Leader, 2/ Extension Agronomist, ODA Coconut Development Project, Thailand, 3/\& 4/ Agronomists, Chumphon Horticultural. Research Centre, 5/ ODA Biometrician, AFRC Institute of Arable Crops Research, Rothamstead Experimental Station, 6/ Coconut Specialist, Department of Agriculture, Thailand. 
In large scale production, the influence of season on yields and prices can be reduced by processing and storage, and delays in returns to inputs can be budgeted for, but smallholders require a continuity of cashflow which precludes any delayed return on both initial investment and subsequent storage in anticipation of price increases.

Thailand, which is subject to a tropical climate, has a coconut industry run predominantly by smallholders and is geared to supplying local demand with only small surpluses available for export. Further, the Thai Tall coconut palm is extremely heterogeneous and conditions in the country arc seen to give minimal support for the use of fertilizer in the existing coconut farming systems.

In 1974 FAO become involved in the demonstration of fertilizer application to coconuts on farms in southern Thailand and used the critical foliar nutrient levels, postulated by L'Institut de Recherches pour les Huiles et Oleagineux (IRHO) (IRHO, 1961), to assess nutrient requirement of the Thai Tall palms in farmers' fields. The resulting recommendation was for $4 \mathrm{~kg}$ of 13:13:21 NPK compound, which was easily available locally, together with between 2 and $5 \mathrm{~kg}$ per palm per year of dolomitic limestone as a cheap source of magnesium, irrespective of soil $\mathrm{pH}$. At present prices and exchange rates this would cost about US $\$ 1.00$ per palm annually, representing an annual investment on an average coconut holding of US $\$ 375.00$, in a region of Thailand having an estimated income of US \$615.00 per capita (Department of Agricultural Extension, 1987). This project ended in 1978 with little success as few farmers adopted the recommendations. The target farmers were large landholders and therefore an unrepresentative sample of ail landholders; also there was no obligation for them to provide the labour inputs for the operations involved in applying fertilizer.

FAO renewed its interests in this work between 1982 and 1985 and this paper look at the results of a series of trials initiated by them in 1984 and continued until 1986.

\section{PROJECT DESCRIPTION, MATERIALS AND METHODS}

Project implementation was in three of the main coconut growing provinces in country, Chumphon, Prachuab Khiri Khan and Surat Thani, ail on the east coast of peninsular Thailand (Figure 1). The project was based at Chumphon Horticultural Research Centre (CHRC) in the approximate centre of the project area. Annual rainfall varied from about $1300 \mathrm{~mm}$ in northern Prachump Khiri Khan to $2000 \mathrm{~mm}$ in Chumphon, falling again to $1800 \mathrm{~mm}$ in Surat Thani, and was influenced by the rain shadow patterns during the south-westerly and north-easterly monsoons. Annual temperature fluctuations and day-length variation decreased from north to south and a more detailed meteorological profile for CHRC has been given elsewhere (Dootson et al, 1986). The soils throughout the project area vary greatly and a profile for the final 30 sites analysed is given in Figure 2 . This shows the preponderance of sandy loams and loamy sands, with a discrete group of beach sands.

Some 50 on-farm trials to demonstrate the use of fertilizer were laid out. Each had 3 plots of 20-25 Thai Tall palms of at least 15 years of age, with unfertilized guard rows. Using a very heterogeneous variety of coconut in plots of about 0.2 ha, systematic errors are inevitable and, where gross visual differences between plots were found, sites were omitted from the final analysis. This elimination, coupled with some natural wastage, reduced the number of sites to 30 and which are listed in Table 1. The number was reduced to 27 in 1986 through further lack of farmer participation.

Palms in a plot received either 0,2 or $4 \mathrm{~kg}$ of 13:13:21 NPK compound fertilizer annually, together with $1 \mathrm{~kg}$ of either dolomitic limestone or kieserite according to soil $\mathrm{pH}$. The fertilizer was given in 2 applications in May and October, except in the swamp areas where, because of problems of access during the monsoons, a single application was given in May. Participating farmers were expected to clear palm bases, apply the fertilizer and then to lightly dig it in, usually with assistance 
Figure 1. Southern Thailand showing the extent of the FAO coconut fertilizer Demonstration

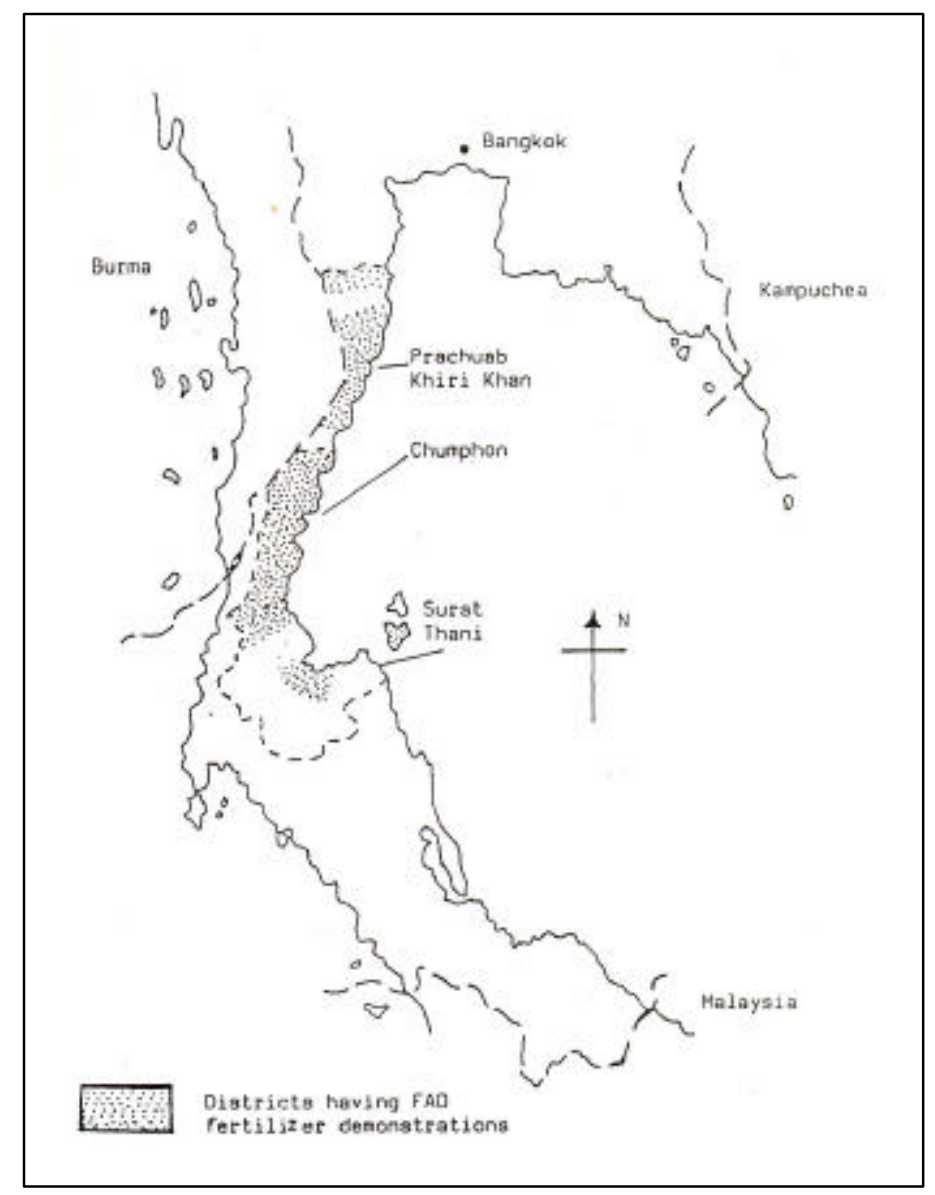

Figure 2. Physical description of soil texture at 30 sites

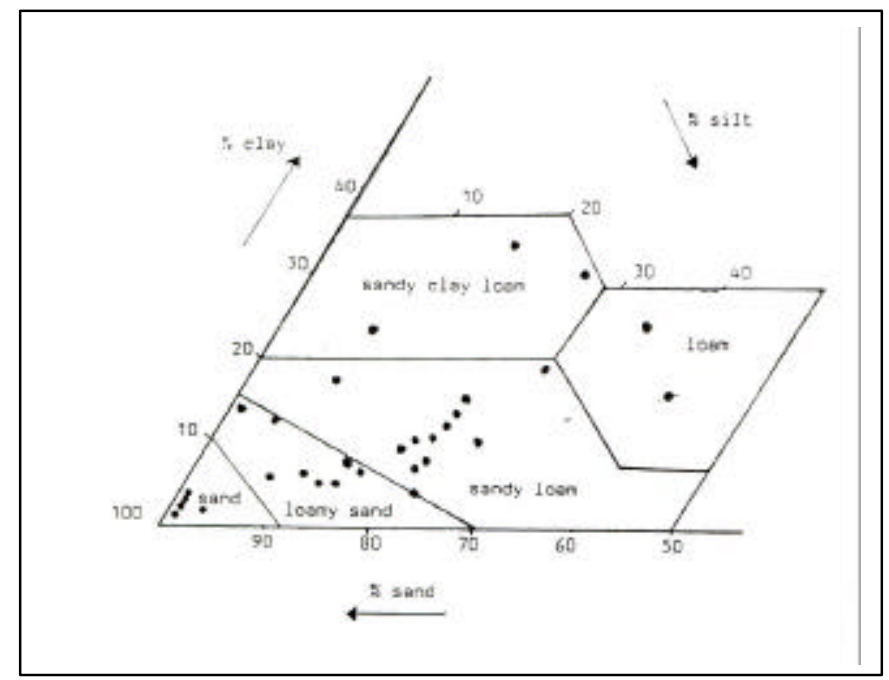


from family or fellow villagers. Palm bases in the unfertilized plots were also cleared and there were no uncultivated controls. First fertilizer applications were made in late 1982.

Nut of at least $10 \mathrm{~cm}$ diameter were counted twice yearly from 1984 to 1986 and the annual totals were used to give an. estimate of treatment effects and, in the absence of accurate farmer yield records, were converted for the purposes of economic analysis to annual yields by using a factor of 0.55 . This average conversion rate will vary considerably between sites. Samples for leaf and soil analysis were taken in March each year. Leaf samples were taken from mid-lamina leaflets of the 14th leaf from the apex and soil samples were taken from $0-15 \mathrm{~cm}$ (topsoil) and $15-30 \mathrm{~cm}$ (subsoil). Analyses were carried out at CHRC, Kohong Rubber Research Centre (KRRC) and at the Department of Agriculture in Bangkok. A small set of duplicate leaf samples were analysed at both KRRC and IRHO, and comparison of the results showed a high degree of replicability with the exception of phosphate, when a failure of voltage stabilizing equipment at KRRC was suspected of affecting the spectro-phot6metric phosphate analysis.

Statistical analysis of the results was done using the program Genstat 5 (1987).

\section{RESULTS AND DISCUSSION}

In each of the three years examined, fertilizer significantly increased the number of nuts counted with a greater increase achieved between 0 and $2 \mathrm{~kg}$ than between 2 and $4 \mathrm{~kg}$ (Table 2). The large differences between years were attributable to patterns initiated by dry season conditions. The low yield in 1984 was a result of the harsh 1983 dry period, which may be assumed to have caused over-compensation in 1985, subsequently lowering the crop in 1986, and thus creating an apparent biennial bearing pattern. Fertilizer application was rarely economical, except when nut prices were assumed to be high. Nut prices at the farm-gate can vary between 0.5 and 4.5 Baht depending on supply and rarely average as much as 2.0 Baht except in years of low yield. The fertilizer cost ratios in Table 2 show the greatest benefit in terms of extra production to occur in 1985, the year of highest overall yield, but then farm-gate prices would be expected to be at their lowest, counteracting any gain resulting from the extra crop.

Despite the great variability between sites and between plots within sites, there is a trend in the response to applied fertilizer. Figures 3, 4 and 5 show the increases in nut production clue to fertilizer application plotted against the nut production of the unfertilized plots. It can be seen that the response to fertilizer is as expected: a greater response for sites having a low or medium yield and a low or decreasing response for more productive sites. There is, however, a suggestion that for some low yielding sites the response is not as good as expected, which could be clue to other factors, such as water deficiency or waterlogging influencing the yields.

As benefits from using fertilizer are small for Thai Tall coconuts under the regimes being studied, any part of the palm population which exhibits a reduced response to fertilizer may give little or no additional profit. Thus sites having inherently high coconut counts should not be given fertilizer and it is possible, given the extreme on-site soil variability exhibited in the sandy loam and loamy sand groups, that this argument can be extended to high-yielding individuals within a population. Table 3 gives the profitability of fertilizer application for the 3 years of the study, summarized for the total production of the unfertilized plots. This confirms the absence of any benefit of applying fertilizer to inherently-productive plots and suggests that if a profit is to be made from applying 2 and $4 \mathrm{~kg}$ of fertilizer to sites whose inherent production is fewer than 60 nuts per year then the farm-gate price must be above 1.5 Baht and 2.0 Baht respectively (25 Baht = US \$1.00). 
Table 1: Fertilizer demonstration sites by province, district and designation

\begin{tabular}{|l|l|l|}
\hline \multicolumn{1}{|c|}{ Province (Changwat) } & \multicolumn{1}{|c|}{ District } & Sesignation \\
\hline Prachuab Khiri Khan & Kuiburi & KUI2 \\
& Muang & PRA2 \\
& Tap Sakae & TAP1, TAP2 \\
& Bang Saphan & BAN1, BAN2, BAN3 \\
\hline Chumphon & Pathiu & PAT1, PAT3 \\
& Tha Sae & THA1 \\
& Muang & CHU1, CHU2, CHU3, CHU4 \\
& & SAW1, SAW2, SAW3 \\
& & TAK1, TAK2, TAK3 \\
& & LAN1, LAN2 \\
& & PHA1 \\
& LAM2, LAM3 \\
\hline Surat Thani & Tha Chana & TCH1, TCH2 \\
& Phunphin & PHU1 \\
& Muang & SUR2, SUR3 \\
\hline
\end{tabular}

Table 2: Response to fertilizer application of Thai Tall coconuts at 30 sites over 3 years

\begin{tabular}{|c|c|c|c|c|c|c|}
\hline \multirow{2}{*}{ Year } & \multirow{2}{*}{$\begin{array}{c}\text { Kg13:13:21 } \\
\text { NPK } \\
\text { Fertilizer/palm }\end{array}$} & \multirow{2}{*}{$\begin{array}{l}\text { Nuts } \\
\text { counted }\end{array}$} & \multirow{2}{*}{$\begin{array}{c}\text { Yield/palm } \\
\text { (55\% of } \\
\text { Nuts) }\end{array}$} & \multicolumn{3}{|c|}{ FCR (1) } \\
\hline & & & & $\mathrm{a}$ & $\mathrm{b}$ & $\mathrm{c}$ \\
\hline \multirow[t]{4}{*}{1984} & 0 & 38.00 & 20.90 & & & \\
\hline & 2 & 49.01 & 26.96 & 1.26 & 1.01 & 0.51 \\
\hline & 4 & 52.97 & 29.13 & 0.86 & 0.69 & 0.34 \\
\hline & \multicolumn{6}{|c|}{2.932} \\
\hline \multirow[t]{4}{*}{1985} & 0 & 56.39 & 31.01 & & & \\
\hline & 2 & 75.86 & 41.72 & 2.23 & 1.79 & 0.89 \\
\hline & 4 & 83.91 & 46.15 & 1.58 & 1.26 & 0.63 \\
\hline & \multicolumn{6}{|c|}{ sed 3.437} \\
\hline \multirow[t]{4}{*}{1986} & 0 & 35.54 & 19.55 & & & \\
\hline & 2 & 46.38 & 25.51 & 1.24 & 0.99 & 0.50 \\
\hline & 4 & 55.56 & 30.56 & 1.15 & 0.92 & 0.46 \\
\hline & \multicolumn{6}{|c|}{ sed 2.984} \\
\hline \multirow{3}{*}{$\begin{array}{l}1984- \\
1986\end{array}$} & 0 & 129.93 & 7146 & & & \\
\hline & 2 & 171.25 & 94.19 & 1.58 & 1.26 & 0.63 \\
\hline & 4 & 192.74 & 106.01 & 1.20 & 0.96 & 0.48 \\
\hline
\end{tabular}

Note (1) FCR = Fertilizer Cost Ratio (value of extra yield/fertilizer cost)

a Assuming mean nut price of $2.5 \mathrm{Baht}$

b Assuming mean nut price of $2.0 \mathrm{Baht}$

c Assuming mean nut price of $1.0 \mathrm{Baht}$

Fertilizer is assumed to cost $6.0 \mathrm{Baht} / \mathrm{kg}$ 
Table 3: The relationship between control plot nut counts on yield response of coconuts to applied fertilizer

\begin{tabular}{|c|c|c|c|c|c|c|c|c|}
\hline Control plot & \multirow{2}{*}{\multicolumn{3}{|c|}{$\begin{array}{c}\text { Nuts counted per palm } \\
\text { Fertilizer rate }\end{array}$}} & Number & \multirow{2}{*}{\multicolumn{2}{|c|}{$\begin{array}{c}\text { Extra } \\
\text { nuts }\end{array}$}} & \multirow{2}{*}{\multicolumn{2}{|c|}{$\begin{array}{c}\text { Breakeven } \\
\text { Nut price (2) }\end{array}$}} \\
\hline Annual total & & & & of & & & & \\
\hline Nut count & $0 \mathrm{Kg}$ & $2 \mathrm{Kg}$ & $4 \mathrm{Kg}$ & Sites (1) & $0-2 \mathrm{Kg}$ & $0-4 \mathrm{Kg}$ & $0-2 \mathrm{Kg}$ & $0-4 \mathrm{Kg}$ \\
\hline More than 100 & 105.75 & 100.30 & 93.45 & 2 & -5.45 & -12.30 & - & - \\
\hline $80-99.99$ & 89.38 & 93.15 & 86.18 & 6 & 3.77 & -3.20 & 5.79 & - \\
\hline $60-79.99$ & 70.63 & 84.39 & 83.88 & 9 & 13.76 & 13.25 & 1.59 & 3.29 \\
\hline $40-59.99$ & 47.72 & 62.78 & 73.95 & 26 & 15.06 & 26.23 & 1.45 & 1.66 \\
\hline $20-39.00$ & 30.54 & 47.91 & 53.71 & 34 & 17.37 & 23.17 & 1.26 & 1.88 \\
\hline Less than 20 & 12.88 & 29.35 & 38.83 & 10 & 16.47 & 25.95 & 1.32 & 1.68 \\
\hline
\end{tabular}

Notes (1) 30 sites in both 1984 and 1985 and 27 sites in 1986

(2) Breakeven nut price $=$

Fertilizer cost $(6 \mathrm{Baht} / \mathrm{Kg})$

Yield estimate (extra nuts x 0.55 )

Although six-monthly coconut counts give the farmers and extension workers a cheap and clear indication of the likely profit from applying fertilizer, the variation of the profitability does imply a considerable risk. To lessen that risk, it is suggested by Dootson et al. 1984, that reduced rates of nitrogen, phosphate and magnesium fertilizer will not reduce the response, provided the level of potash is maintained.

One way of increasing the reliability and precision of nut counts as a method of estimating the response to fertilizer would be to find some physical or chemical aspects of the soil or palm that also influence the palm's production. Such measurements may indicate why sites having similar initial counts differ in their responses to applied fertilizer. As much of the influence of fertilizer is expected to be on floral initiation and flowering which occur at least a year before harvest, the nut production counts were compared with the results of the leaf and soil analyses of the samples taken in the previous year, summaries being given in Tables 4 and 5 .

Subsequent analyses were confined to fitting regression models, involving the leaf and soil analysis data, to the coconuts yields. Each year was analysed separately and all the plots from each site were included. Because the plots received different amounts of fertilizer, and extra factor, for fertilizer level, was introduced to monitor if and how the regression equations changed.

Table 6 lists the correlation coefficients for those variates, recorded from the leaf and soil analyses, which produced a significant linear regression with nut count. Foliar nitrogen is the only variate which appears for each year. The counts in 1984 were also influenced by a number of soil factors associated with the water-holding capacity for 1983, a particularly severe dry season. The positive correlations for organic matter can easily be linked to the other correlations. More organic matter is expected in clay soils than in sandy soils, which tend to be inversely linked. Also pH usually increases with organic matter as does the level of magnesium. Some correlations with soil and leaf phosphate levels can be expected, as the levels accumulate in the soil. This explains the appearance in 1986 of significant correlations. The significant negative correlations between nuts counted and foliar calcium and magnesium levels are less easy to explain but maybe they suppress the uptake of the monovalent cations of both potassium and sodium, which are known to be closely related to yield. Increased demand for potassium uptake may have resulted from the greater yield levels in 1985 and associated large nutrient exports. 
Figure 3. Influence of fertilizer on Nut count 1984

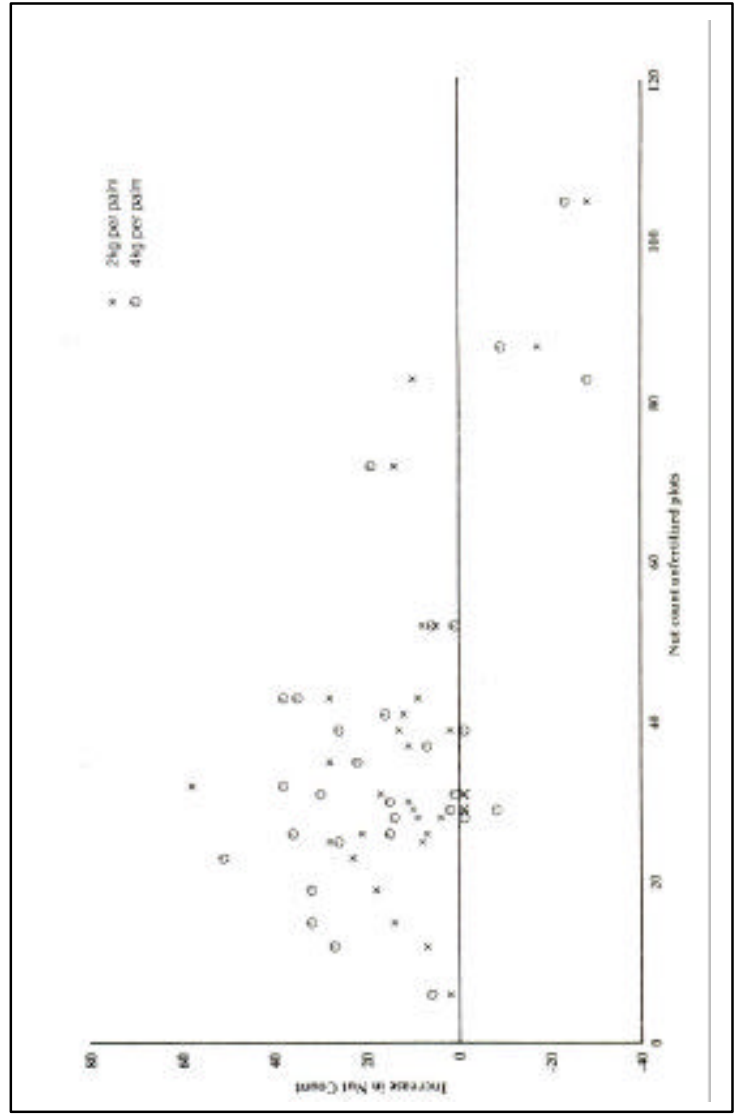

Figure 4. Influence of Fertilizer on nut counts 1985

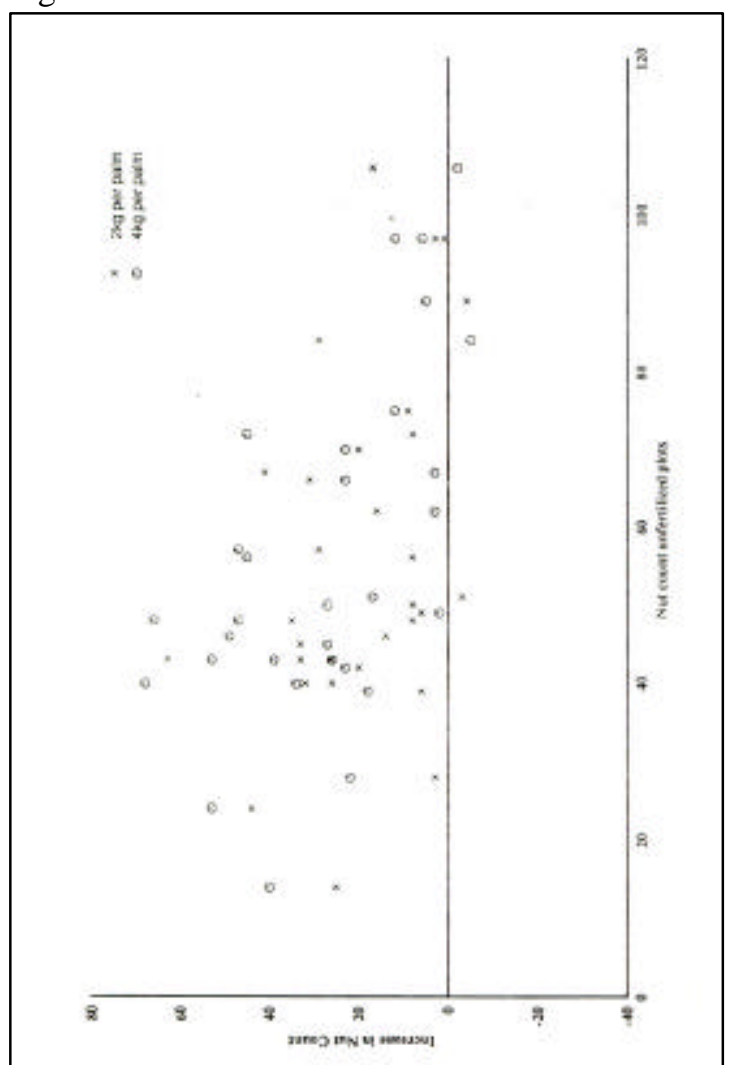


Figure 5. Influence of fertilizer on nut counts 1986

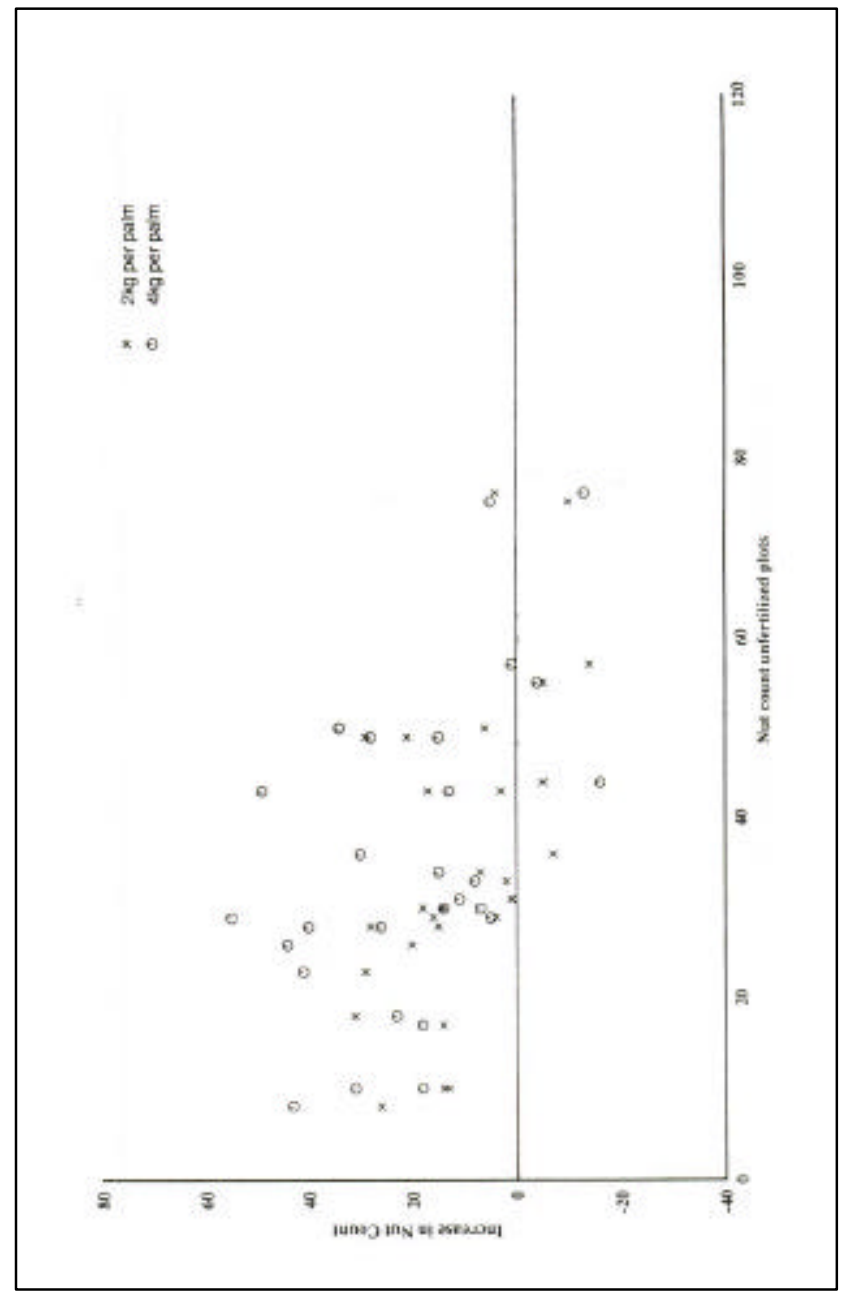

Figure 6. Influence of foliar nitrogen on nut production in each year

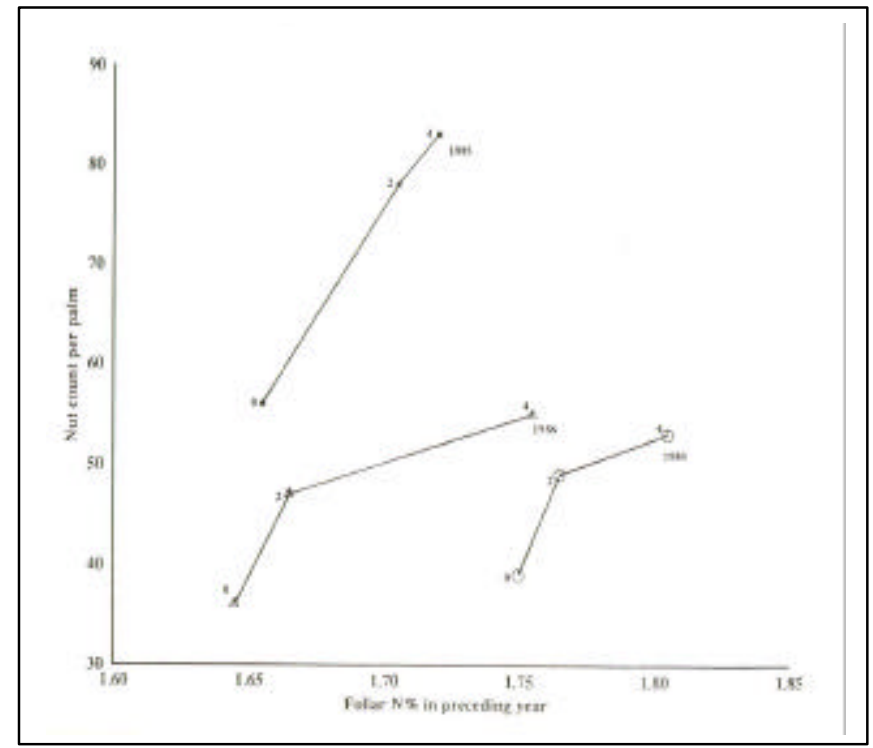


Table 4: Ranges and means of foliar analysis results

Table 4: Ranges and means of foliar analysis results

\begin{tabular}{|c|c|c|c|c|c|c|c|c|}
\hline \multirow[t]{2}{*}{ Year } & \multirow{2}{*}{$\begin{array}{c}\mathrm{Kg} \\
\text { Fertilizer }\end{array}$} & \multirow[t]{2}{*}{ Range } & \multicolumn{6}{|c|}{ Foliar Characteristics $(\%)$} \\
\hline & & & $\mathrm{N}$ & $\mathrm{P}$ & $\mathrm{K}$ & $\mathrm{Ca}$ & $\mathrm{Mg}$ & $\mathrm{Na}$ \\
\hline 1983 & 0 & $\begin{array}{l}\text { Minimum } \\
\text { Mean } \\
\text { Maximum }\end{array}$ & $\begin{array}{l}1.47 \\
1.75 \\
1.98 \\
\end{array}$ & $\begin{array}{l}0.088 \\
0.143 \\
0.310 \\
\end{array}$ & $\begin{array}{l}0.400 \\
0.036 \\
1.401 \\
\end{array}$ & $\begin{array}{l}0.178 \\
0.316 \\
0.559 \\
\end{array}$ & $\begin{array}{l}0.160 \\
0.266 \\
0.460 \\
\end{array}$ & $\begin{array}{l}0.092 \\
0.238 \\
0.629 \\
\end{array}$ \\
\hline & 2 & $\begin{array}{l}\text { Minimum } \\
\text { Mean } \\
\text { Maximum }\end{array}$ & $\begin{array}{l}1.53 \\
1.76 \\
2.04 \\
\end{array}$ & $\begin{array}{l}0.094 \\
0.125 \\
0.294 \\
\end{array}$ & $\begin{array}{l}1.410 \\
1.657 \\
1.930 \\
\end{array}$ & $\begin{array}{l}0.200 \\
0.318 \\
0.578 \\
\end{array}$ & $\begin{array}{l}0.200 \\
0.269 \\
.0 .369 \\
\end{array}$ & $\begin{array}{l}0.102 \\
0.209 \\
0.335 \\
\end{array}$ \\
\hline & 4 & $\begin{array}{l}\text { Minimum } \\
\text { Mean } \\
\text { Maximum } \\
\end{array}$ & $\begin{array}{l}1.60 \\
1.81 \\
2.00 \\
\end{array}$ & $\begin{array}{c}0.088 \\
0.126 \\
0.26 \\
\end{array}$ & $\begin{array}{l}0.534 \\
1.022 \\
1.556 \\
\end{array}$ & $\begin{array}{l}0.197 \\
0.319 \\
0.654 \\
\end{array}$ & $\begin{array}{l}0.160 \\
0.265 \\
0.400 \\
\end{array}$ & $\begin{array}{l}0.088 \\
0.219 \\
0.378 \\
\end{array}$ \\
\hline 1984 & 0 & $\begin{array}{l}\text { Minimum } \\
\text { Mean } \\
\text { Maximum }\end{array}$ & $\begin{array}{l}1.41 \\
1.66 \\
1.93 \\
\end{array}$ & $\begin{array}{l}0.085 \\
0.119 \\
0.142 \\
\end{array}$ & $\begin{array}{l}0.600 \\
1.143 \\
1.568 \\
\end{array}$ & $\begin{array}{l}0.094 \\
0.288 \\
0.731 \\
\end{array}$ & $\begin{array}{l}0.170 \\
0.283 \\
0.410 \\
\end{array}$ & $\begin{array}{l}0.110 \\
0.247 \\
0.450 \\
\end{array}$ \\
\hline & 2 & $\begin{array}{l}\text { Minimum } \\
\text { Mean } \\
\text { Maximum }\end{array}$ & $\begin{array}{l}1.43 \\
1.70 \\
2.07 \\
\end{array}$ & $\begin{array}{l}0.098 \\
0.123 \\
0.157 \\
\end{array}$ & $\begin{array}{l}0.222 \\
1.155 \\
1.669 \\
\end{array}$ & $\begin{array}{l}0.167 \\
0.280 \\
0.538 \\
\end{array}$ & $\begin{array}{l}0.180 \\
0.274 \\
0.390 \\
\end{array}$ & $\begin{array}{l}0.011 \\
0.225 \\
0.486 \\
\end{array}$ \\
\hline & 4 & $\begin{array}{l}\text { Minimum } \\
\text { Mean } \\
\text { Maximum }\end{array}$ & $\begin{array}{l}1.30 \\
1.72 \\
2.03 \\
\end{array}$ & $\begin{array}{l}0.098 \\
0.125 \\
0.165 \\
\end{array}$ & $\begin{array}{l}0.694 \\
1.173 \\
1.576 \\
\end{array}$ & $\begin{array}{l}0.177 \\
0.304 \\
0.776 \\
\end{array}$ & $\begin{array}{l}0.160 \\
0.257 \\
0.380 \\
\end{array}$ & $\begin{array}{l}0.089 \\
0.250 \\
0.443 \\
\end{array}$ \\
\hline 1985 & 0 & $\begin{array}{l}\text { Minimum } \\
\text { Mean } \\
\text { Maximum }\end{array}$ & $\begin{array}{l}1.31 \\
1.65 \\
2.06 \\
\end{array}$ & $\begin{array}{l}0.095 \\
0.119 \\
0.156 \\
\end{array}$ & $\begin{array}{l}0.632 \\
1.190 \\
1.626 \\
\end{array}$ & $\begin{array}{l}0.172 \\
0.311 \\
0.629 \\
\end{array}$ & $\begin{array}{l}0.150 \\
0.249 \\
0.440 \\
\end{array}$ & $\begin{array}{l}0.047 \\
0.218 \\
0.476 \\
\end{array}$ \\
\hline & 2 & $\begin{array}{l}\text { Minimum } \\
\text { Mean } \\
\text { Maximum }\end{array}$ & $\begin{array}{l}1.43 \\
1.66 \\
1.91 \\
\end{array}$ & $\begin{array}{l}0.098 \\
0.123 \\
0.154 \\
\end{array}$ & $\begin{array}{l}0.321 \\
1.219 \\
1.739 \\
\end{array}$ & $\begin{array}{l}0.178 \\
0.299 \\
0.584 \\
\end{array}$ & $\begin{array}{l}0.140 \\
0.235 \\
0.370 \\
\end{array}$ & $\begin{array}{l}0.029 \\
0.205 \\
0.588 \\
\end{array}$ \\
\hline & 4 & $\begin{array}{l}\text { Minimum } \\
\text { Mean } \\
\text { Maximum }\end{array}$ & $\begin{array}{l}1.49 \\
1.75 \\
1.95\end{array}$ & $\begin{array}{l}0.114 \\
0.129 \\
0.143\end{array}$ & $\begin{array}{l}0.779 \\
1.235 \\
1.574\end{array}$ & $\begin{array}{l}0.202 \\
0.321 \\
0.533\end{array}$ & $\begin{array}{l}0.130 \\
0.231 \\
0.390\end{array}$ & $\begin{array}{l}0.060 \\
0.217 \\
0.523\end{array}$ \\
\hline
\end{tabular}

Table 7 expresses the multiple regression models fitted to the nut count data, for each of the 3 years under study. Foliar nitrogen is present in all models even when the factor for amounts of fertilizer has been included. The percentage variation which can be accounted for by these regression models is low, never reaching $40 \%$, which suggests that other unknown variables may be influential in determining yield. Such variables might include potassium levels in tissues younger than the 14th leaf normally sampled, the interaction between cations in older tissues, effective soil depth, as demonstrated by Loganathan et al (1976) and the chemical analysis of the actual water table. Certainly the methodology developed for sampling soil in shallow rooting annuals may be of little value where coconuts and, presumably, many other tree crops are grown. 
Table 5: Ranges and means of soil characteristics measured over 3 years

\begin{tabular}{|c|c|c|c|c|c|c|c|}
\hline \multirow{3}{*}{ Character } & \multirow{3}{*}{ Range } & \multicolumn{3}{|c|}{ Topsoil } & \multicolumn{3}{|c|}{ Subsoil } \\
\hline & & & $\mathrm{g}$ fertili & & & fertiliz & \\
\hline & & 0 & 2 & 4 & 0 & 2 & 4 \\
\hline $\mathrm{pH}$ & $\begin{array}{l}\text { Minimum } \\
\text { Mean } \\
\text { Maximum }\end{array}$ & $\begin{array}{l}3.1 \\
5.8 \\
8.1 \\
\end{array}$ & $\begin{array}{l}3.8 \\
5.7 \\
8.2 \\
\end{array}$ & $\begin{array}{l}3.8 \\
5.7 \\
8.1 \\
\end{array}$ & $\begin{array}{l}3.5 \\
5.8 \\
8.3 \\
\end{array}$ & $\begin{array}{l}4.4 \\
5.7 \\
8.2 \\
\end{array}$ & $\begin{array}{l}3.6 \\
5.6 \\
8.3 \\
\end{array}$ \\
\hline Ec (mhos) (1) & $\begin{array}{l}\text { Minimum } \\
\text { Mean } \\
\text { Maximum }\end{array}$ & $\begin{array}{l}0.001 \\
0.026 \\
0.140 \\
\end{array}$ & $\begin{array}{l}0.001 \\
0.028 \\
0.201 \\
\end{array}$ & $\begin{array}{l}0.001 \\
0.029 \\
0.201 \\
\end{array}$ & $\begin{array}{l}0.001 \\
0.023 \\
0.124 \\
\end{array}$ & $\begin{array}{l}0.001 \\
0.027 \\
0.150 \\
\end{array}$ & $\begin{array}{l}0.001 \\
0.031 \\
0.200 \\
\end{array}$ \\
\hline Organic matter & $\begin{array}{l}\text { Minimum } \\
\text { Mean } \\
\text { Maximum }\end{array}$ & $\begin{array}{c}0.16 \\
1.76 \\
6.1 \\
\end{array}$ & $\begin{array}{l}0.43 \\
1.79 \\
6.56 \\
\end{array}$ & $\begin{array}{l}0.23 \\
1.78 \\
6.30 \\
\end{array}$ & $\begin{array}{l}0.10 \\
1.23 \\
6.66 \\
\end{array}$ & $\begin{array}{l}0.10 \\
1.21 \\
6.00 \\
\end{array}$ & $\begin{array}{l}0.10 \\
1.33 \\
6.66 \\
\end{array}$ \\
\hline $\begin{array}{l}\text { Available P } \\
\text { (ppm) }\end{array}$ & $\begin{array}{l}\text { Minimum } \\
\text { Mean } \\
\text { Maximum }\end{array}$ & $\begin{array}{c}1 \\
7 \\
38 \\
\end{array}$ & $\begin{array}{c}1 \\
22 \\
100\end{array}$ & $\begin{array}{c}1 \\
37 \\
260\end{array}$ & $\begin{array}{c}1 \\
5 \\
30\end{array}$ & $\begin{array}{c}1 \\
7 \\
51\end{array}$ & $\begin{array}{c}1 \\
12 \\
96\end{array}$ \\
\hline $\begin{array}{l}\text { Available K } \\
\text { (ppm) }\end{array}$ & $\begin{array}{l}\text { Minimum } \\
\text { Mean } \\
\text { Maximum }\end{array}$ & $\begin{array}{c}6 \\
66 \\
212 \\
\end{array}$ & $\begin{array}{c}16 \\
78 \\
316 \\
\end{array}$ & $\begin{array}{c}12 \\
86 \\
408 \\
\end{array}$ & $\begin{array}{c}10 \\
50 \\
243 \\
\end{array}$ & $\begin{array}{c}10 \\
59 \\
308 \\
\end{array}$ & $\begin{array}{c}12 \\
59 \\
376 \\
\end{array}$ \\
\hline $\begin{array}{l}\text { Available } \mathrm{Ca} \\
\text { (ppm) }\end{array}$ & $\begin{array}{l}\text { Minimum } \\
\text { Mean } \\
\text { Maximum }\end{array}$ & $\begin{array}{c}55 \\
400 \\
2850 \\
\end{array}$ & $\begin{array}{c}62 \\
448 \\
3300 \\
\end{array}$ & $\begin{array}{c}68 \\
469 \\
3960 \\
\end{array}$ & $\begin{array}{c}50 \\
339 \\
2720 \\
\end{array}$ & $\begin{array}{c}45 \\
415 \\
4060 \\
\end{array}$ & $\begin{array}{c}55 \\
419 \\
4860 \\
\end{array}$ \\
\hline $\begin{array}{l}\text { Available } \mathrm{Mg} \\
\text { (ppm) }\end{array}$ & $\begin{array}{l}\text { Minimum } \\
\text { Mean } \\
\text { Maximum }\end{array}$ & $\begin{array}{c}6 \\
89 \\
740 \\
\end{array}$ & $\begin{array}{c}6 \\
89 \\
750 \\
\end{array}$ & $\begin{array}{c}11 \\
84 \\
830 \\
\end{array}$ & $\begin{array}{c}4 \\
67 \\
830 \\
\end{array}$ & $\begin{array}{c}6 \\
70 \\
750 \\
\end{array}$ & $\begin{array}{c}4 \\
67 \\
750 \\
\end{array}$ \\
\hline Sand $(\%)$ & $\begin{array}{l}\text { Minimum } \\
\text { Mean } \\
\text { Maximum }\end{array}$ & $\begin{array}{l}41 \\
73 \\
98 \\
\end{array}$ & $\begin{array}{l}- \\
- \\
-\end{array}$ & $\begin{array}{l}- \\
- \\
-\end{array}$ & $\begin{array}{l}- \\
- \\
-\end{array}$ & $\begin{array}{l}- \\
- \\
-\end{array}$ & $\begin{array}{l}- \\
- \\
-\end{array}$ \\
\hline Silt (\%) & $\begin{array}{l}\text { Minimum } \\
\text { Mean } \\
\text { Maximum }\end{array}$ & $\begin{array}{c}1 \\
16 \\
41 \\
\end{array}$ & $\begin{array}{l}- \\
- \\
-\end{array}$ & $\begin{array}{l}- \\
- \\
-\end{array}$ & $\begin{array}{l}- \\
- \\
-\end{array}$ & $\begin{array}{l}- \\
- \\
-\end{array}$ & $\begin{array}{l}- \\
- \\
-\end{array}$ \\
\hline Clay (\%) & $\begin{array}{l}\text { Minimum } \\
\text { Mean } \\
\text { Maximum }\end{array}$ & $\begin{array}{c}1 \\
11 \\
33 \\
\end{array}$ & $\begin{array}{l}- \\
- \\
-\end{array}$ & $\begin{array}{l}- \\
- \\
-\end{array}$ & $\begin{array}{l}- \\
- \\
-\end{array}$ & $\begin{array}{l}- \\
- \\
-\end{array}$ & $\begin{array}{l}- \\
- \\
-\end{array}$ \\
\hline
\end{tabular}

Note (1) Ec levels in 1984 were $10 \%$ of the values in 1983 and 1985 and an error is Suspected within analysis procedures. 
Table 6: Significant linear regressions between nut count and leaf and soil analysis characteristics, without allowance for fertilizer levels

\begin{tabular}{|l|c|c|c|}
\hline \multirow{2}{*}{ Characteristic } & \multicolumn{3}{|c|}{ Year of Nut Count (1) } \\
\cline { 2 - 4 } & $\begin{array}{c}1984 \\
(\mathrm{n}=70)\end{array}$ & $\begin{array}{c}1985 \\
(\mathrm{n}=85)\end{array}$ & $\begin{array}{c}1986 \\
(\mathrm{n}=79)\end{array}$ \\
\hline $\begin{array}{l}\text { Foliar nitrogen } \\
\text { Foliar phosphate }\end{array}$ & 0.389 & 0.434 & 0.514 \\
$\begin{array}{l}\text { Foliar calcium } \\
\text { Topsoil pH }\end{array}$ & & 0.357 \\
Topsoil organic matter & -0.233 & & -0.237 \\
Topsoil phosphate & 0.368 & & -0.221 \\
Subsoil organic matter & 0.439 & & 0.220 \\
Subsoil magnesium & 0.277 & & \\
Topsoil sand \% & -0.264 & & \\
Topsoil clay \% & 0.343 & & \\
\hline
\end{tabular}

Note (1) Foliar and soil sampling one year earlier

Table 8: Regression analyses (for the 3 years) of coconuts production at 30 sites Against leaf and soil characteristics with and without a factor for applied fertilizer

\begin{tabular}{|c|c|c|c|c|}
\hline Year & Fitted characteristics & $\begin{array}{l}\text { Regression } \\
\text { Coefficient }\end{array}$ & $\begin{array}{l}\text { Standard } \\
\text { Error }\end{array}$ & $\begin{array}{c}\text { Percentage } \\
\text { Variance } \\
\text { Accounted for }\end{array}$ \\
\hline \multirow[t]{2}{*}{1984} & $\begin{array}{l}\text { Constant } \\
\text { Organic matter (subsoil) } \\
\text { Foliar nitrogen }\end{array}$ & $\begin{array}{c}-40.1 \\
6.5 \\
43.0\end{array}$ & $\begin{array}{l}26.7 \\
1.89 \\
15.3\end{array}$ & 25.5 \\
\hline & $\begin{array}{l}\text { Constant } \\
2 \mathrm{Kg} \text { fertilizer } \\
4 \mathrm{Kg} \text { fertilizer } \\
\text { Organic matter (subsoil) } \\
\text { Foliar nitrogen }\end{array}$ & $\begin{array}{c}-38.7 \\
9.4 \\
10.7 \\
6.6 \\
38.4\end{array}$ & $\begin{array}{c}26.3 \\
4.83 \\
4.9 \\
1.84 \\
15.1\end{array}$ & 29.4 \\
\hline \multirow[t]{2}{*}{1985} & $\begin{array}{l}\text { Constant } \\
\text { Foliar nitrogen } \\
\text { Phosphate (topsoil) }\end{array}$ & $\begin{array}{c}-45.9 \\
67.5 \\
0.1108\end{array}$ & $\begin{array}{c}25.4 \\
14.9 \\
0.0531\end{array}$ & 21.0 \\
\hline & $\begin{array}{l}\text { Constant } \\
2 \mathrm{Kg} \text { fertilizer } \\
4 \mathrm{Kg} \text { fertilizer } \\
\text { Foliar nitrogen } \\
\text { Organic matter (topsoil) } \\
\text { Magnesium (topsoil) }\end{array}$ & $\begin{array}{c}-46.4 \\
16.8 \\
23.9 \\
57.7 \\
7.6 \\
-0.0726 \\
\end{array}$ & $\begin{array}{c}23.4 \\
5.04 \\
5.05 \\
13.6 \\
2.5 \\
0.0323 \\
\end{array}$ & 37.7 \\
\hline \multirow[t]{2}{*}{1986} & $\begin{array}{l}\text { Constant } \\
\text { Foliar nitrogen } \\
\text { Potassium (topsoil) } \\
\text { Phosphate (topsoil) }\end{array}$ & $\begin{array}{c}-79.7 \\
70 \\
0.082 \\
0.341 \\
\end{array}$ & $\begin{array}{c}20.3 \\
11.8 \\
0.035 \\
0.157 \\
\end{array}$ & 33.6 \\
\hline & $\begin{array}{l}\text { Constant } \\
2 \mathrm{Kg} \text { fertilizer } \\
4 \mathrm{Kg} \text { fertilizer }\end{array}$ & $\begin{array}{l}-67.8 \\
10.2 \\
13.4\end{array}$ & $\begin{array}{l}20.6 \\
3.99 \\
4.21\end{array}$ & 37.9 \\
\hline
\end{tabular}




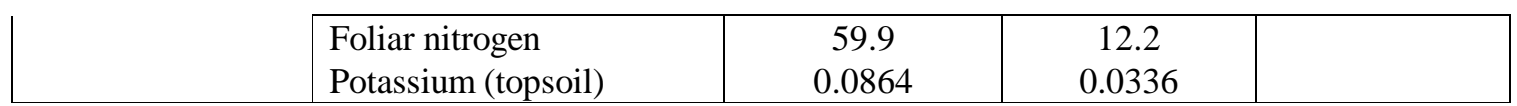

Table 8: Significant correlation coefficients between coconut production and the leaf and soil characteristics at 20 sites with and without plots receiving fertilizer

\begin{tabular}{|l|l|c|c|}
\hline Year & \multicolumn{1}{|c|}{ Characteristics } & $\begin{array}{c}\text { Unfertilizerd } \\
\text { Plots only }\end{array}$ & $\begin{array}{c}\text { Including } \\
\text { Fertilized plots }\end{array}$ \\
\hline \multicolumn{3}{|c|}{ Linear } & - \\
\hline 1984 & Foliar nitrogen & - & 0.308 \\
\hline 1985 & Foliar phosphate & -517 & - \\
& Foliar nitrogen & - & 0.397 \\
& Topsoil phosphate & - & 0.259 \\
\hline 1986 & Foliar nitrogen & 0.689 & 0.468 \\
& Foliar phosphate & 0.519 & 0.437 \\
& Topsoil & 0.641 & 0.359 \\
& Subsoil phosphate & 0.759 & - \\
& Topsoil Ec & - & 0.296 \\
\hline
\end{tabular}

Regression analysis of all data from all sites fails to identify the conditions of the control plots which can be associated with the inherent coconut numbers. Also, some sites which exhibit extremes of soil characteristics had a considerable leverage on the regressions fitted. The analyses were therefore repeated excluding the following sites: the two fertile loams (THA 1 and PHA 1); the three alluvial sandy clay loams with high organic matter and low pH (PHU 1, SUR 2 and SUR 3); and physically discrete group of sands (KUI 2, PAT 3, LAM 3, TAK 1 and LAN 2). Finally, an analysis using only the unfertilized plots was done to check for consistency; the main results are summarised in Table 8. Using only the unfertilized plots, there is no consistent relationship with foliar nitrogen; foliar and soil phosphate achieve more consistent significance. This suggests that phosphate more, strongly determines inherent yield levels than does nitrogen, an observation that is affirmed when the fertilized plots are included in the analysis when the influence of foliar nitrogen is again dominant. The sites selected for this reduced analysis, are, ail sandy loams and loamy sands from recently cleared forested areas, which are substantially eroded, and have very low available phosphate levels. Overall there is little evidence to suggest that leaf or soil analysis can be used to predict likely response to applied fertilizer.

\section{CONCLUSIONS}

Application of compound fertilizer increased the yield of Thai Tall coconuts but the increases were rarely profitable given the farmgate prices. It is therefore clear that lower fertilizer recommendations need to be made if smallholder coconut farmers are expected to achieve profitable increases in yield through fertilizer application. This not only means reducing overall rates but also improving the balance of nutrients given. Evidence, suggests that nitrogen and phosphate rates should be reduced while maintaining potassium content. There is little to suggest that magnesium is needed except where $\mathrm{pH}$ is low and it can be applied as cheap dolomitic limestone.

As the magnitude of fertilizer response declines with the basic inherent levels of yield, farmers can estimate the likely benefit from applying fertilizer by counting the number of nuts twice, with a 6-month interval, and adding the two counts together. A total of more than 60 nuts per palm would suggest a risk of not making a profit from applying fertilizer but, where the count is lower than this and provided the palms appear reasonably healthy, there is likely to be a profitable response to 
potassium or high-K compound fertilizers. Existing high-K compounds such as 13:13:21 contain too much $\mathrm{N}$ and $\mathrm{P}$ and a maximum ratio of 2:2:5 is suggested for these nutrients.

Foliar and soil analyses proved to be an unsatisfactory tool to measure, yield production. Greater success obtained elsewhere in relating leaf nutrient levels to yields suggests that the methodology requires specific definition within Thailand, especially with regard to time of sampling. Improvement may be obtained by sampling a younger leaf, especially for the real potassium status. It is not thought that sampling of the top $30 \mathrm{~cm}$ of the soil is sufficient except where water is never limiting. Methods for deeper sampling are required in most situations, possibly to determine effective soil depth and to ascertain conditions in the real water table.

\section{ACKNOWLEDGMENTS}

This paper is presented with the permission of the Department of Agriculture of the Royal Thai Government and of the Overseas Development Administration of the British Government.

The massive contribution to this paper by staff members of FAO is gratefully acknowledged, especially that of F.J. Hensey who was responsible for initiating the trials herein reported, and H. Braun and K. Zschernitz of the Fertilizer Programme for their interest and support.

\section{REFERENCES}

Department of Agricultural Extension (DOAE) (1987). Regional per capita incomes in Thailand. In Statistical Information for Agriculture

DOOTSON, J., KANONG KLODPENG, PANIT NGANGORANATIGARN and MALIWAN RATTANAPRUK (1984). Effects of fertilizer application on early vegetative growth and precocity of MYD x WAT hybrid coconuts in Thailand. Presented at International Conference on Cocoa and Coconuts, Kuala Lumpur.

DOOTSON, J., MALIWAN RATTANAPRUK and WIT SUWANNAWUTH (1986). Coconut development in Thailand and its stimulation by cocoa. Planter, 62, 519-530 0

GENSTAT COMMITTEE (1987). GENSTAT 5 Reference Manual, Oxford University Press

IRHO (1961). General instructions for hand pollination and leaf sampling for foliar diagnosis of the coconut palm

LOGANATHAN, P., PERERA, K.S.O. and ABEYWARDENA, V. (1976). Influence of soil type and selected soil morphological properties on the yield of coconut (Cocos Nucifera L) in Sri Lanka 11. Walpita Estate, Kotadeniyana. Ceylon Coconut Quarterly. 27, 13-21.

VOX UEXHULL, H.R. (1985). Chapter 40. Potassium in Agriculture, 929-954, University of Wisconsin. 